\title{
ELABORATION OF THE RECIPE OF THE FERMENTED MILK DESSERT FOR CHILD FOOD
}

\author{
Nadya Dzyuba \\ Department of restaurant and health food technology \\ Odessa National Academy of Food Technologies \\ 112 Kanatna str., Odessa, Ukraine, 65039 \\ dzyubanadya282@gmail.ru \\ Liudmyla Valevskaya \\ Department of grain storage technology \\ Odessa National Academy of Food Technologies \\ 112 Kanatna str., Odessa, Ukraine, 65039 \\ ludmilavvalev@ukr.net \\ Vita Atanasova \\ Department of restaurant and health food technology \\ Odessa National Academy of Food Technologies \\ 112 Kanatna str., Odessa, Ukraine, 65039 \\ vitaatanasova@gmail.com \\ Alena Sokolovskaya \\ Department of grain storage technology \\ Odessa National Academy of Food Technologies \\ 112 Kanatna str., Odessa, Ukraine, 65039 \\ sokolovskaya_alena@meta.ua
}

\begin{abstract}
Using the tabular processor MS Excel 2007 there was elaborated the recipe of the fermented milk dessert for child food. The recipe of this dessert consists of (mass. $\%$, g): fermented milk curd -54 , jam -23 , honey -8 , sesame -4 , cream -6 , collagen hydrolyzate (glutin) - 5. This dessert is a source of vitamin C and covers near $40 \%$ of a child daily need in it. At the expanse of introducing glutin in the dessert composition, protein content in the ready product increased that covers from $11,28 \%$ to $22,56 \%$ of a daily need. This dessert is also rich in calcium, so one portion of it covers $25 \%$ of a child need.

Based on theoretical qualimetry methods there was realized the complex estimation of the dessert quality. The hierarchic structure of ready product properties was presented, including organoleptic and physical-chemical parameters and also ones of the food and biological value at storage.

The estimation of microbiological and organoleptic parameters at storage give a possibility to state, that the new fermented milk dessert will be competitive at the consumer market. The storage life of this product is 5 days at the temperature $(4 \pm 2){ }^{\circ} \mathrm{C}$.

Keywords: fermented milk dessert, qualimetric estimation, structural-mechanical properties of food products.

\section{Introduction}

The base of the scientific-technical policy in the sphere of health food is a satisfaction of human physiological needs in essential food substances and organization of the balanced health food. Such food system allows to provide the physiological need of the world population in necessary nutrients, to improve indices of its health, to concentrate means, resources and scientific-technical potential of world countries on a solution of problems, vitally important for nations.

The improvement of the food structure of the Ukrainian population provides the increase of food products manufacturing due to the improvement of existent and creation of new technologies of functional food products. Such products must have: balanced chemical composition; low energetic value; low content of sugar and saturated fatty acids; high content of functional and sanitary-prophylactic ingredients; absolute safety for a human.
\end{abstract}


People eat sugary meals every day. So, today scientists of the food industry and also victuallers try to make desserts not only nice and tasty but also useful. At the expanse of introduction of biologically active additives in recipes content, products acquire functional properties. Traditional sugary meals are considered as: baked confectionary (pastries, cakes, pies, fruit cakes, muffins, biscuits), confectionary (candies, chocolates, jam) and also milk products (ice-cream, soufflé, curd desserts) $[1,2]$.

At the elaboration of combined food products on the milk base, scientists most often combine milk with raw material ingredients of a vegetable origin. Such ingredients are rich in prebiotics, food fibers [3, 4], biologically active substances [5-9], full value proteins of a vegetable origin [10, 11], essential polyunsaturated fatty acids [12, 13].

Gelatin is most known among structure-creating food preparations, used in the milk production $[14,15]$.

Features of gelatin introduction complicate the technological process in the milk production.

Being related to food fibers, collagen hydrolyzate (gelatin) gives expressed treating-prophylactic properties to manufactured products [16]. At the expanse of lysine and proline, it penetrates the biological mechanism of connective tissues creation in the human organism fast and may act as a biologically active additive with chondroprotective properties.

Thus, it is prospective to elaborate the fermented milk dessert, enriched with collagen hydrolyzate (glutin). Such product may be posed as a prophylactic one for gerodietic food and for a growing organism in child food.

Thus, the aim of this work is the elaboration of the fermented milk product, enriched with collagen hydrolyzate (glutin) for child food.

The following tasks were formulated for attaining this aim:

- to elaborate the recipe and technology of the fermented milk dessert with the high content of nutrients;

- to realize the commodity estimation of the new product quality;

- to determine optimal storage terms of the elaborated fermented milk dessert.

\section{Materials and Methods}

The studies were realized on the base of modern scientific laboratories:

- Department of restaurant and health food technology, Odessa National Academy of Food Technologies, Ukraine;

- chemistry, expertise and safety of food products of Odessa National Academy of Food Technologies, Ukraine;

- biochemistry, microbiology and physiology of food of Odessa National Academy of Food Technologies, Ukraine;

- laboratory of Physical-chemical institution, named after A.V. Bogatsky (Odessa, Ukraine);

- biochemistry and physiology of plants of Odessa selective-genetic institute of the National center of seed-growing and variety studies, UAAS (Odessa, Ukraine).

The following equipment was used for studies:

- for preparing the dessert "Martyshka" was used the blender (PHILIPS HR-1633/80, China), refrigerated cabinet (RC-0,4 MC, Mari El Republic, Russia), electric stove (SE-4SH, Russia), washstand and electric bench scales (Rotex RSK 10-P, China);

- for adhesive strength determination - "Reotest-II" (Russia);

- for fluidity determination - Bostwick consistometer (Russia);

- for amino acid content determination - amino acid analyzer Hitachi L-8900 (Japan). in Table 1.

Microbiological parameters were determined according to normative documents, presented

The adhesive strength characterizes the specific effort of the adhesive contact destruction. The adhesive strength depends on: binding energy in a product; fullness of the product contact with a surface; surface relief; interphase surface energy; conditions of the contact formation (pressure, temperature, contact duration and so on). 
Table 1

Microbiological parameters of curd dessert

\begin{tabular}{cr}
\hline Parameters & Norm (SSTC 4552: \\
\hline Coliform colon bacillus bacteria, CCU in $0,1 \mathrm{~cm}^{3}$ & $\begin{array}{r}\text { Not observed } \\
\text { (SSTC IDF 73A) }\end{array}$ \\
Pathogenic microorganisms, including Salmonella, in 25 g of a product & $\begin{array}{r}\text { Not observed } \\
\text { (SSTC IDF 93A) }\end{array}$ \\
Quantity of molds, CCU in 1 g of a product is no more than & 50 \\
Quantity of yeast, CCU in 1 g of a product is no more than & SS 10444.12 \\
Staphylococcus aureus, in 0,01 g of a product & 100 \\
\end{tabular}

The adhesion characteristic is a separation force $-\mathrm{P}(\mathrm{kg})$, related to the area of the contacting surface $-\mathrm{S}\left(\mathrm{m}^{2}\right)$. It is named an adhesion strength, adhesion tension $-\mathrm{T}\left(\mathrm{kg} / \mathrm{m}^{2}\right)$.

$$
\mathrm{T}=\frac{\mathrm{P}}{\mathrm{S}}
$$

where $\mathrm{T}$ - adhesive strength, $\mathrm{kg} / \mathrm{m}^{2} ; \mathrm{P}$ - separation effort, $\mathrm{kg} ; \mathrm{S}$ - area of the contact between the food mass and surface, $\mathrm{m}^{2}$.

The dessert fluidity was determined using the Bostwick viscosimeter (Fig. 1) by determining the distance of the material flow under the effect of the own mass for $30 \mathrm{~s}$.

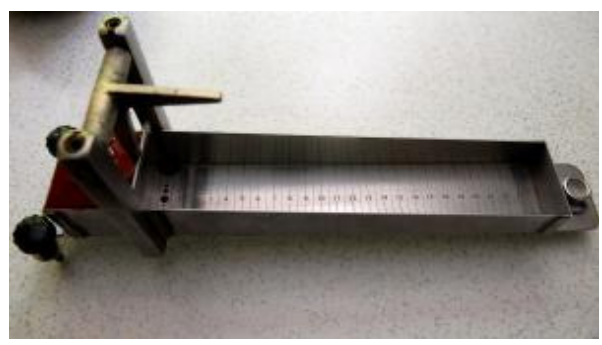

Fig. 1. Bostwick consistometer

The maximal received value of the product course in the chute center and the minimal one by the chute sides are determined, and the mean value is calculated.

$$
\mathrm{L}=\frac{\left(\mathrm{L}_{\min }+\mathrm{L}_{\max }\right)}{2}
$$

where $\mathrm{L}$ - fluidity, $\mathrm{cm} / 30 \mathrm{~s} ; \mathrm{L}_{\min }$ - minimal value of fluidity by the chute sides, $\mathrm{cm} / 30 \mathrm{~s}$; $\mathrm{L}_{\max }-\max -$ imal fluidity value in the cute center, $\mathrm{cm} / 30 \mathrm{~s}$.

\section{Experimental procedures}

To determine the dessert recipe the linear programming in Excel Solver inset of the tabular processor MS Excel 2007 was applied by the methodology, described in [17]. At that the main problem was the construction of the correspondent mathematical model that includes the following stages: 
- determination of the aim of the study;

- selection of the optimality criterion;

- revelation of main limitations;

- mathematical formalization.

The main criteria at the raw material selection for the dessert became the high food value and a possibility to combine components to receive a product with the increased biological value and high organoleptic parameters. The following raw materials were selected for the projected dessert composition: fermented milk curd, jam, sesame, cream, glutin. The main aim of the recipe optimization is a final product with a balanced protein-carbohydrate composition.

The recipe of the elaborated dessert is presented in Table 2.

Table 2

The recipe of studied dessert

\begin{tabular}{ccc}
\hline No. in order & Raw material name & Raw material quantity, g \\
\hline 1 & Milk fermented curd & 54 \\
2 & Jam & 23 \\
3 & Honey & 8 \\
4 & Sesame & 4 \\
6 & Cream & 6 \\
\end{tabular}

The technological scheme of the studied dessert manufacturing includes the following technological operations: fermented milk curd is comminuted using the blender; glutin is subjected to the temperature processing during 30 minutes (such time of technological processing is conditioned by the fact that glutin swells, sorbing hydroxyl groups on itself; collagen fibers become soft and in further will be able to demonstrate hydrocolloid properties) and cooled; curd, glutin, cream, honey and jam are mixed and shaken during 5 minutes; sesame is fried for 3-4 minutes and cooled; the received food mass is mixed, portioned, cooled to the temperature $8-10{ }^{\circ} \mathrm{C}$ and presented to a consumer.

Glutin use in the dessert composition influences structural-mechanical properties of the food system.

For determining the food system adhesive strength there were used plates of different materials (vulcanite, ceramics and aluminium). The dynamics of the interaction between the food system and device plates was realized during 15 minutes with the measurement pitch 5 minutes [18].

For determining the curd dessert viscosity, the standard fat concentration was studied using fermented milk curd $-0,2 \%, 9 \%, 15 \%$ on the viscosimeter "Reotest II". It allows to determine the dynamic (effective) structural viscosity in the diapason from $10^{-2}$ to $10^{4} \mathrm{~Pa} \cdot \mathrm{s}$, at the defined deformation speeds from 0,2 to $1,3 \cdot 10^{3} \mathrm{~s}^{-1}$ in the temperature interval from $-30{ }^{\circ} \mathrm{C}$ to $150{ }^{\circ} \mathrm{C}$.

"Reotest II" has the set of cylinders for measuring systems with different viscosity. The dynamometer range selector allows to select a shift tension diapason ( $\tau 1$ and 11$)$ with their ratio 1:10. Such possibility provides the shift tension measuring in the wide interval without changing a measuring device. Before measuring, the internal cylinder was fixed on the axis of the measuring shaft. A sample of the studied material was weighted on technical scales, placed in the internal cylinder, inset in the socket of the viscosimeter body and fixed by turning the clamp. Both cylinders were placed in the two-wall thermostatic container and were thermostated for 30 minutes at $20^{\circ} \mathrm{C}$. The temperature of this dessert presentation at enterprises of restaurant economy is $20^{\circ} \mathrm{C}$, so, it is necessary to determine its viscosity at this temperature. To make the temperature of the studied dessert sample even by the whole volume, the thermostating time was selected as 30 minutes.

A dependency between the shift tension and shift speed was measured in materials with the structural viscosity in the studied dessert to characterize the studied dessert sample in the aspect 
of its rheological properties. The measuring was started at low values of the shift speed and $\alpha$ value readings were deducted at the indicator device.

The tangential tension value was found by the formula:

$$
\tau=\mathrm{Z} \cdot \alpha
$$

where $\tau$ - shift tension, $10^{-1} \mathrm{~Pa} ; \mathrm{Z}$ - cylinder constant, $10^{-1}$ scale value; $\alpha$ - scale readings at the indicating device.

The dynamic viscosity value was calculated by the formula:

$$
\eta=\frac{\tau}{\gamma} \cdot 100
$$

where $\eta$-dynamic viscosity, Pa·s; $\gamma$-deformation speed, $\mathrm{s}^{-1}$.

The received data demonstrated that glutin introduction decreases the quantity of free moisture and increases the quantity of bound one, the product receives the firmer structure. At experiences on the rotary viscosimeter, it was revealed, that the dessert relates to dilatatant non-newtonian fluids.

The dessert viscosity was determined on the Bostwick consistometer as following. The little section of it was filled with the dessert mass (volume $75 \mathrm{ml}$ ) and distributed evenly by volume. Then the time was noted and the bolt was open. The distance, passed by the studied material on the bottom of the calibrated part of the device under the effect of the own weight during 30 seconds, was measured. The final result was considered as the arithmetical mean of the results of three parallel measurements [18].

Thus, the optimal temperature for this dessert presentation at enterprises of restaurant economy is the temperature diapason $8-16^{\circ} \mathrm{C}$.

Parameters of food, biological and energetic value were studied in the elaborated dessert.

The vitamin composition was determined using high-liquid chromatography on the column $(4 \times 150 \mathrm{~mm})$, filled with sorbent "Separon C-18"with granulation $7 \mathrm{mcm}$ (CJSC "Nauchpribor", Russia). The elution speed is $1,1 \mathrm{~cm}^{3} / \mathrm{min}$.

The mineral composition of the product was determined by ashing a sample. The dry ashing was realized at the high temperature (near $500^{\circ} \mathrm{C}$ ) in the crucible in the muffler under conditions, excluding a loss of ash elements, during 6 hours.

Based on data about the dessert chemical composition, it may be stated, that consumption of the fermented milk dessert "Martyshka" will be useful for the human organism, because it contains the balanced composition of macronutrients (proteins, fats, carbohydrates) that corresponds to the norm for a healthy human 1:1:4.

The following stage of the work was the study of changes of microbiological and organoleptic parameters using the accelerated ASLT test at the process of the dessert storage. The model of ASLT test includes the following problems:

- to elaborate the program of the study realization;

- to determine the influence of storage conditions on the quality of dessert samples;

- to calculate the prognosticated storage term for the dessert.

ASLT testing may be used in different processes of a quality loss or food spoilage that the adequate kinetic model is known for. Spoilage processes of food products are expressed by changes of such quality parameters as: organoleptic, physical-chemical, microbiological and biological. All functions are closely connected with each other and their successive realization is a process of the products quality management. This process may include all production stages and may be presented as a "quality loop".

To predict the fact storage term of the dessert there was used a dependency of the change process of commodity parameters and ones of dessert safety on the term and temperature of storage. The main quality parameters were: organoleptic and microbiological ones. 
The ready dessert were divided in samples with the mass $50 \mathrm{~g}$, their temperature at storage was changed from $5{ }^{\circ} \mathrm{C}$ to $15^{\circ} \mathrm{C}$, with the pitch $5^{\circ} \mathrm{C}$, and storage term from 12 to 72 hours with the pitch 12 hours. Manufacturing and storage of the dessert were realized in equal conditions, changing storage parameters according to the set plan, under conditions, similar to ones of modern restraints.

According of the results of received data it was established, that the optimal storage term of the elaborated fermented milk dessert in waterproof glass package is:

- at the storage temperature $5{ }^{\circ} \mathrm{C}-60 \ldots 72$ hours;

- at the storage temperature $10^{\circ} \mathrm{C}-36 \ldots 48$ hours;

- at the storage temperature $15^{\circ} \mathrm{C}$ to 24 hours.

\section{Conclusions}

1. Using Excel Solver inset of MS Excel 2007 tabular processor there was elaborated the recipe of the fermented milk dessert with the balanced protein-carbohydrate composition. The following raw material components were selected for the elaborated composition: fermented milk curd, jam, honey, sesame, cream, glutin.

2. The received data of the study of structural-mechanical properties and the fermented milk dessert demonstrated that it may be referred to dilatant non-newtonian fluids. The optimal temperature for the dessert presentation at enterprises of restaurant economy is the temperature diapason $8-16^{\circ} \mathrm{C}$.

3. ASLT testing of the elaborated dessert under different storage conditions allows to state that its rational storage conditions are 5 days at the temperature $(4 \pm 2){ }^{\circ} \mathrm{C}$.

\section{References}

[1] Blake, L. H., Jenner, C. F., Barber, A. R., Gibson, R. A., O’Neill, B. K., Nguyen, Q. D. (2014). Effect of waxy flour blends on dough rheology and bread quality. International Journal of Food Science \& Technology, 50 (4), 926-933. doi: 10.1111/ijfs.12710

[2] Iorgachova, K., Makarova, O., Khvostenko, K. (2016). Technological characteristics of yeast-containing cakes production using waxy wheat flour. Food science and technology, 10 (4), 37-41. doi: 10.15673/fst.v10i4.252

[3] Belozerova, M. S., Evstigneeva, T. N., Grigoreva, A. A. (2016). Development of composition and technology of dairy dessert with carrot fiber. Proceedings of the Voronezh State University of Engineering Technologies, 2, 140-147. doi: 10.20914/2310-1202-2016-2-140-147

[4] Donskaya, G. A., Asafov, V. A., Andreeva, E. A. (2016). Effect of food additives introduced into dairy dessert on antioxidant activity of biological objects. Food Processing: Techniques and Technology, 43 (4), 5-10.

[5] Coman, M. M., Verdenelli, M. C., Cecchini, C., Silvi, S., Vasile, A., Bahrim, G. E. et. al. (2013). Effect of buckwheat flour and oat bran on growth and cell viability of the probiotic strains Lactobacillus rhamnosus IMC 501®, Lactobacillus paracasei IMC 502® and their combination SYNBIO ${ }^{\circledR}$, in synbiotic fermented milk. International Journal of Food Microbiology, 167 (2), 261-268. doi: 10.1016/j.ijfoodmicro.2013.09.015

[6] Yasni, S., Maulidya, A. (2014). Development of Corn Milk Yoghurt Using Mixed Culture of Lactobacillus delbruekii, Streptococcus salivarus, and Lactobacillus casei. HAYATI Journal of Biosciences, 21 (1), 1-7. doi: 10.4308/hjb.21.1.1

[7] Ferreira, S. M., Caliari, M., Soares Junior, M. S., Del Pino Beleia, A. (2014). Infant dairy-cereal mixture for the preparation of a gluten free cream using enzymatically modified rice flour. LWT - Food Science and Technology, 59 (2), 1033-1040. doi: 10.1016/j.lwt.2014.06.047

[8] Casarotti, S. N., Penna, A. L. B. (2015). Acidification profile, probiotic in vitro gastrointestinal tolerance and viability in fermented milk with fruit flours. International Dairy Journal, 41, 1-6. doi: 10.1016/ j.idairyj.2014.08.021

[9] Rudakova, T. V. (2015). Technology of products curd is for child's food with the use of products of processing of grain. Grain products and mixed fodders, 1 (58), 9-14. doi: 10.15673/2313-478x.58/2015.46009 
[10] Zare, F., Champagne, C. P., Simpson, B. K., Orsat, V., Boye, J. I. (2012). Effect of the addition of pulse ingredients to milk on acid production by probiotic and yoghurt starter cultures. LWT - Food Science and Technology, 45 (2), 155-160. doi: 10.1016/j.lwt.2011.08.012

[11] Antonova, A., Dzyuba, N. (2017). Optimization of the composition of muffins on the basis of essential indicators of chemical compound of the confectionary product "Vupi pai." Automation of technological and business-processes, 9 (1), 28-32. doi: 10.15673/atbp.v9i1.499

[12] Dal Bello, B., Torri, L., Piochi, M., Zeppa, G. (2015). Healthy yogurt fortified with n-3 fatty acids from vegetable sources. Journal of Dairy Science, 98 (12), 8375-8385. doi: 10.3168/jds.2015-9688

[13] Ar'en, B., Yohen, E., Dzhina, K., Hendrik, S. M. (2018). Pat. No. 2006126682 RU. Produkty, alternativnye slivkam. MPK A23C13/00 (2006.01) A23C19/068. No. 2006126682/13; declareted: 16.11.2004; published: 27.01.2008, Bul. No. 13, 10.

[14] Plekhanova, E. A., Bannikova, A. V., Ptichkina, N. M. (2013). Development of technology and compositions of milk desserts with dietary purposes. Food Processing: Techniques and Technology, 3, 53-57.

[15] Ivanets, G. E., Svetkina, E. A., Potapov, A. N. (2012). Using of plant raw material for manufacture of aerated milk-based products. Food Processing: Techniques and Technology, 2. Available at: http:// fptt-journal.ru/?page $=$ archive $\&$ jrn $=25 \& \operatorname{article}=10$

[16] Dzyuba, N., Telezhenko, L., Valevskaya, L., Zemlyakova, E. (2017). Comprehensive research into quality of the immunostimulating beverage "immuno plus." Eastern-European Journal of Enterprise Technologies, 2 (10 (86)), 4-11. doi: 10.15587/1729-4061.2017.98199

[17] Telezhenko, L. M., Dzyuba, N. A., Kashkano, M. A., Valevska, L. O. (2016). Osnovy naukovykh doslidzhen. Kherson: Hrin D. S., 192.

[18] Burdo, A. K., Dzyuba, N. A., Zemlyakova, O. V. (2016). Metodychni vkazivky do vykonannya laboratornykh robit z kursu «Teoretychni osnovy kharchovykh tekhnolohiy». Odessa: ONAKhT, 48. 